\title{
HASIL TANGKAPAN IKAN TARGET DAN NON TARGET YANG TERTANGKAP DENGAN GILL NET DI MUARA SAMPAI KAWASAN GUDANG ARANG SUNGAI MARO KABUPATEN MERAUKE
}

\section{TARGET AND NON- TARGET CATCH CAPTURED BY GILL NET AT THE MARO RIVER, MERAUKE}

\author{
Bonny Lantang ${ }^{1 *}$, Sendy Lely Merly ${ }^{1}$ \\ Jurusan Manajemen Sumberdaya Perairan, Faperta, Universitas Musamus \\ *lantang@unmus.ac.id merly@unmus.ac.id
}

Diterima (receive) : 04 Juli 2019; Disetujui (accepted) : 4 Oktober 2019

\begin{abstract}
ABSTRAK
Penelitian ini bertujuan untuk mengetahui jenis ikan target dan ikan non-target serta untuk mengetahui komposisi spesies, kelimpahan relatif, indeks keanekaragaman dan indeks dominansi yang ditangkap di Muara ke Area Gudang Arang di Sungai Maro, Kabupaten Merauke. Teknik pengambilan data dilakukan dengan menggunakan metode Purposive Random Sampling. Untuk mengetahui keberadaan spesies, dilakukan studi komposisi spesies ikan, kelimpahan relatif, indeks keanekaragaman dan indeks dominansi. Hasil penelitian menunjukkan bahwa tangkapan ikan target adalah 11 spesies dan non-target sebanyak 6 spesies. Kelimpahan hasil tangkapan relatif pada ikan target tertinggi diperoleh pada ikan Bawal putih (Rhinoprenes Pentanemus) dengan nilai 54,47\% sedangkan ikan non-target tertinggi berada di White Baung (Cinetodus crassilabri) dengan nilai $82,75 \%$. Indeks keanekaragaman tangkapan spesies ikan target adalah 1,41 sehingga dikategorikan sebagai keanekaragaman sedang, dalam spesies non-target adalah 0,73 dan rendah. Tidak ada jenis yang mendominasi tangkapan, baik ikan target maupun ikan non-target.
\end{abstract}

Kata kunci: Ikan Target, ikan non-taget, Sungai Maro, indeks dominansi, indeks keanekaragaman

\begin{abstract}
This study aimed to determine the types of target and non-target species and to know the composition of the species, relative abundance, diversity index and dominance index caught in the Estuary to Gudang Arang Areas of Maro River, Merauke Regency. Data were collected by using the Purposive Random Sampling method. To find out the availability of species, we assessed the species composition, relative abundance, diversity index and dominance index. The results showed that the catches of the target species were 11 species and non-target as many as 6 species. The abundance of the relative catch in the highest target fish was white Bawal fish (Rhinoprenes Pentanemus) with the value of $54.47 \%$ while the highest non-target fish was in White Baung (Cinetodus crassilabri) with a value of $82.75 \%$. The diversity index of the target species catch was 1.41 so it is categorized as moderate diversity, whereas for the non-target species it was 0.73 with the low category. There was no a dominant catch, both target and non-target species.
\end{abstract}

Keywords: Species target, non taget species, Maro River, dominance index, diversity index 


\section{PENDAHULUAN}

Kabupaten Merauke memiliki potensi sumberdaya perikanan baik laut, rawa dan sungai yang sangat besar yang telah dimanfaatkan oleh nelayan setempat untuk meningkatkan kesejahteraannya. Data jumlah potensi ikan konsumsi lokal per $\mathrm{kg}$ menurut jenis per Distrik khusus untuk Kabupaten Merauke sebanyak 7.841 .987 kg (Merauke dalam Angka, 2014). Salah satu sungai yang dimanfaatkan oleh masyarakat dalam melakukan penangkapan ikan adalah Sungai Maro. Sungai Maro merupakan salah satu potensi perikanan dimana terdapat berbagai jenis ikan dan biota lainnya. Jenis alat tangkap yang secara umum digunakan nelayanan Kelurahan Kamahedoga yaitu dari gill net dengan ukuran mesh size 3,4,5 dan 10 inchi.

Penelitian sebelumnya tentang kajian hasil tangkapan ikan di Sungai Maro telah dilakukan oleh Lantang (2015), tentang Komposisi Jenis Ikan dan Pengaruh Faktor Lingkungan pada Ikan Yang Tertangkap Di Muara Sungai Maro Kabupaten Merauke. Astuti, (2008) tentang Inventarisasi Sumberdaya Ikan di Sungai Maro bagian Tengah Kabupaten Merauke. Mote (2019) tentang Kelimpahan Jenis Ikan Di Muara Sungai Maro Kelurahan Karang Indah Merauke, Papua. Tetapi penelitian terkait komposisi jenis ikan target dan non terget belum pernah dilakukan di perairan Sungai Maro. Hal ini sangat penting mengingat bahwa penangkapan ikan ditujukan untuk melakukan penangkapan ikan yang memiliki nilai ekonomis tinggi dengan menangkap ikan yang menjadi target penangkapan dan miminimalkan ikan non terget. Adanya konsep penangkapan ikan ramah lingkungan yang mengharuskan pengguna memanfaatkan sumberdaya dengan bijak untuk menjaga keberlanjutan sumberdaya perikanan serta penggunan alat tangkap yang menangkap ikan multi spesiaes menjadi perhatian bersama untuk menekan hasil tangkapan sampingan (by-catch).

Penelitian ini bertujuan untuk mengetahui jenis ikan yang menjadi target penangkapan dan ikan non target serta mengatahui komposisi jenis, kelimpahan relatif, indeks keanekaragaman dan indeks dominansi yang tertangkap di Muara sampai Kawasan Gudang Arang Sungai Maro Kabupaten Merauke. Diharapkan penelitian ini menjadi informasi bagi semua pihak yang membutuhkan data terkait jenis ikan terget dan non target dalam penentuan kebijakan pengelolaan sumberdaya di Kabupaten Merauke. 


\section{DATA DAN METODE}

\section{Lokasi Dan Waktu Penelitian}

Penelitian ini telah dilaksanakan di

Muara sampai Kawasan Gudang Arang
Sungai Maro Kabupaten Merauke. Penelitian berlangsung selama tiga bulan yaitu bulan Oktober - Desember 2017.

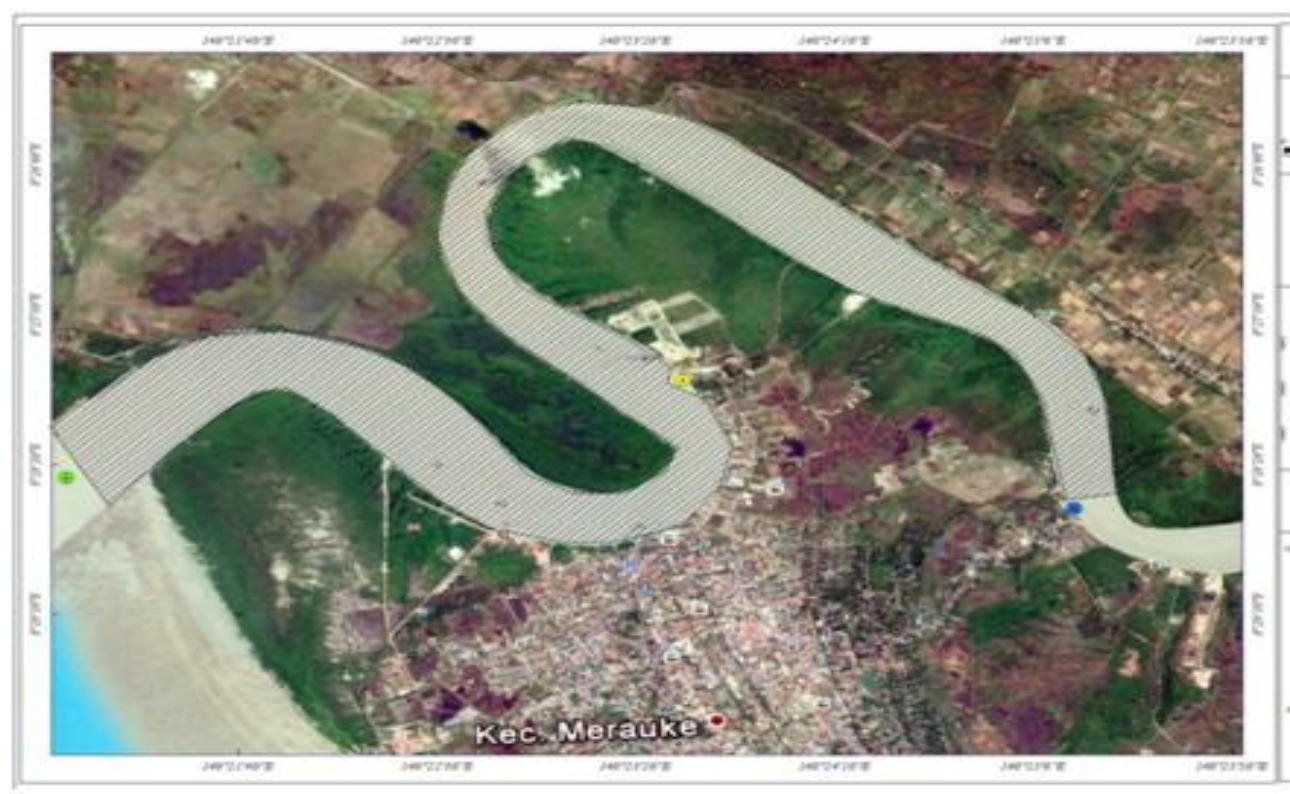

Gambar 1. Peta lokasi penelitian

\section{Alat dan Bahan}

Alat dan bahan yang digunakan adalah : jaring insang hanyut, kamera, kalkulator, buku tulis, penggaris, plastik sampel, kertas label, ember plastik, tissue, baki plastik, buku identifikasi, alkohol $70 \%$ dan sampel ikan yang tertangkap.

\section{Teknik Pengambilan Data}

Teknik pengambilan data dilakukan dengan menggunakan metode Purposive Random Sampling. Pengambilan data dengan prosedur yaitu : sampel ikan yang tertangkap dimasukkan kedalam wadah, selanjutnya diidentifikasi di Labortorium Jurusan Manajemen Sumberdaya Perairan
Fakultas pertanian Universitas Musamus. Identifikasi mengacu pada buku panduan identifikasi Allen (1989), Allen et al., (2000) dan website www.fishbase.org. untuk menentukan nama spesies hasil tangkapan yang diperoleh. Pengambilan sampel dilakukan pada area penangkapan selama 4 kali dalam seminggu selama tiga bulan.

\section{Analisa Data}

1. Komposisi Jenis

Komposisi jenis diperoleh dari data spesiaes hasil tangkapan yang diperoleh selama penelitian.

2. Kelimpahan Relatif 
Perhitungan kelimpahan relatif setiap spesies ikan dilakukan dengan perhitungan persentase jumlah. Persamaan yang digunakan adalah :

$$
K r=\frac{n i}{N} \times 100 \%
$$

Keterangan :

$\mathrm{Kr}=$ Kelimpahan relatif

$\mathrm{ni}=$ Jumlah individu spesies ke-i

$\mathrm{N}=$ Jumlah total individu semua spesies

3. Indeks Keanekaragaman

Untuk menentukan keanekaragaman ikan digunakan indeks Shannon- Wiener (Odum, 1971) :

$$
H^{\prime}=-\sum_{i=1}^{n}\left(\frac{n i}{N}\right) \ln \left(\frac{n i}{N}\right)
$$

Dimana :

$\mathrm{H}^{\prime}=$ Indeks Diversitas Shannon-Wiener

$\mathrm{ni}=$ Jumlah individu spesies ke-i

$\mathrm{N}=$ Jumlah individu semua spesies

Kisaran nilai indeks keanekaragaman menurut Kreb (1989) adalah :

$\mathrm{H}^{\prime}<1$ : keanekaragaman rendah, penyebaran jumlah individu tiap spesies rendah dankestabilan komunitas rendah.

$1<\mathrm{H}^{\prime}<3$ : keanekaragaman sedang, penyebaran jumlah individu tiap spesies sedang dan kestabilan komunitas sedang.
$\mathrm{H}^{\prime}>3$ : keanekaragaman tinggi, penyebaran jumlah individu tiap spesies tinggi dan kestabilan komunitas tinggi.

4. Indeks dominansi Simpson (Odum,1996)

Keterangan:

C : Indeks Dominasi simpson

$\mathrm{Ni} \quad$ : Jumlah Individu spesies ke-i

$\mathrm{N} \quad$ : Jumlah individu semua spesies Legende (1983) menyatakan nilai indeks dominansi berkisar antara 0-1;

$\checkmark \quad$ Indeks 1 menunjukkan dominansi oleh satu jenis spesies sangat tinggi (hanya terdapat satu jenis pada satu stasiun).

$\checkmark$ Sedangkan indeks 0 menunjukkan bahwa diantara jenis-jenis yang ditemukan tidak ada yang dominansi.

\section{HASIL DAN PEMBAHASAN}

\section{Komposisi Jenis Hasil Tangkapan}

Berdasarkan tabel 1, diketahui bahwa jumlah hasil tangkapan ikan target dan non target selama penelitian yaitu 286 ekor yang terdiri dari ikan target sebanyak 257 ekor dan ikan non terget sebanyak 29 ekor. Jenis ikan terbanyak yaitu ikan Bawal Putih (Rhinoprenes Pentanemus) dengan jumlah 140 ekor, diikuti oleh ikan Terubuk 
(Lebtobrama sp.) sebanyak 52 ekor dan ikan

Kakap Batu (Lantjanus griseus) sebanyak 30

ekor. Untuk ikan non target total keseluruhan mencapai 29 ekor, dengan jenis yang paling banyak yaitu ikan Baung Putih

(Cinetodus crassilabris) sebanyak 24 ekor.

Tabel 1. Komposisi jenis ikan hasil tangkapan

\begin{tabular}{|c|c|c|}
\hline No & Jenis Ikan & Jumlah \\
\hline \multicolumn{3}{|c|}{ IKAN TARGET } \\
\hline 1 & Ikan Bawal Putih (Rhinoprenes Pentanemus) & 140 \\
\hline 2 & Ikan Bawal Hitam (Parastromateus niger) & 1 \\
\hline 3 & Ikan Kakap Batu (Lantjanus griseus) & 30 \\
\hline 4 & Ikan Terubuk (Lebtobrama sp.) & 52 \\
\hline 5 & Ikan Kuro (Polydactylus plebiu) & 6 \\
\hline 6 & Ikan Gulamah (Argyrosomus amoyensis) & 8 \\
\hline 7 & Ikan Kakap Putih (Lates Calcalifer) & 8 \\
\hline 8 & Ikan Kakap Cina (Nibea Sguamaosa) & 2 \\
\hline 9 & Ikan Tenggiri (Scomberomorus comeroso) & 1 \\
\hline 10 & Ikan Kurau (Eleutheronema tetradactylum) & 8 \\
\hline 11 & Ikan Tembang (Thryssa scratchleyi) & 1 \\
\hline & Jumlah & 257 \\
\hline \multicolumn{3}{|c|}{ IKAN NON TARGET } \\
\hline 1 & Ikan Baung Putih (Cinetodus crassilabris) & 24 \\
\hline 2 & Ikan Baung Merah (Cinetodus froggatti) & 1 \\
\hline 3 & Ikan Pari Burung (Rhinoptera javanica) & 1 \\
\hline 4 & Ikan Sembilan (Polototus canus) & 1 \\
\hline 5 & Ikan Lidah (Cynoglossus Lingua) & 1 \\
\hline 6 & Ikan Hiu (Carcharhinus amboinensis) & 1 \\
\hline & Jumlah & 29 \\
\hline
\end{tabular}

Sesuai hasil penelitian diperoleh 17 jenis ikan yang terdiri dari 11 jenis ikan target dan 6 jenis ikan non target. Hal ini lebih rendah jika dibanding penelitian Lantang et al., (2019) ${ }^{b}$ di Sungai Kumbe Kabupaten Merauke dengan jumlah jenis yang ditemukan yaitu 22 spesies, hal ini diduga disebabkan oleh perbedaan musim dan waktu pengambilan data yang berbeda. Jumlah hasil tangkapan selama penelitian bervariasi yaitu pada bulan Oktober dengan jumlah hasil tangkapan untuk ikan target sebanyak 142 ekor dan untuk ikan non target sebanyak 8 ekor. Pada bulan November jumlah hasil tangkapan untuk ikan target sebanyak 97 ekor dan untuk ikan non target sebanyak 13 ekor. Sedangkan pada bulan Desember ditemukan hasil tangkapan ikan target sebanyak 10 ekor dan ikan non target sebanyak 11 ekor. Menurunya hasil tangkapan pada bulan Desember diduga oleh perubahan musim yang seharusnya ditandai dengan intensifnya hujan sehingga menurunkan faktor lingkungan seperti suhu terutama pada wilayah muara sungai yang cenderung dangkal. Lantang et al., (2019) ${ }^{a}$ 
bahwa belum intensifnya musim hujan yang pada bulan tersebut yang seharusnya sudah ditandai dengan curah hujan yang tinggi mengakibatkan intensitas cahaya matahari masih cukup kuat untuk menghangatkan badan air.

Hasil penelitian juga menunjukan bahwa selama penelitian di Sungai Maro terdapat jenis ikan sebagai hasil tangkapan terbanyak yaitu Bawal Putih (Rhinoprenes Pentanemus). Hal ini diduga bahwa musim penangkapan jenis Ikan Bawal paling banyak terjadi pada bulan September - November. Nelayan menyebutkan bahwa bulan tersebut tergolong dalam musim ikan Bawal karena hasil tangkapan paling banyak terjadi pada bulan-bulan tersebut jika dibandingkan dengan waktu-waktu lain.

\section{Hasil limpahan Relatif ( $\mathbf{K r}$ )}

Dari hasil penelitian, tingginya nilai kelimpahan relatif untuk ikan terget pada ikan Bawal Putih (Rhinoprenes Pentanemus) dengan prentase sebesar 54,47\% hampir sama dengan penelitian Lantang et al., $(2019)^{b}$ di Sungai Kumbe tetapi dengan jenis ikan yang berbeda bahwa hasil kelimpahan relatif menunjukan bahwa di Sungai Kumbe jenis ikan yang memiliki kelimpahan relatif tertinggi adalah jenis Cinetodus crassilabris dengan persentase sebesar 41,48\%. Lagler (1972) menjelaskan suatu spesies ikan di alam memiliki hubungan erat dengan keberadaan makanannya, ikan tersebut dapat bertahan hidup jika terdapat jenis makanan yang disukainya, ketersediaan makanan merupakan faktor yang menentukan jumlah dan dinamika populasi, pertumbuhan, reproduksi, serta kondisi ikan yang ada di suatu perairan.

\section{Kelimpahan Relatif ( Kr)}

Dari hasil tangkapan ikan di Muara sampai Gudang Arang Sungai Maro memiliki nilai Kelimpahan Relatif $(\mathrm{Kr})$ setiap spesies ikan target maupun non target yang berbeda - beda. Kelimpahan relatif tertinggi untuk ikan terget diperoleh pada ikan Bawal Putih (Rhinoprenes Pentanemus) dengan prentase sebesar 54,47\%, ikan Terubuk (Lebtobrama sp.) sebesar 20,23\%, ikan Kakap Batu (Datnioides campbelli) sebesar 11,67\%. 
Tabel 2. Nilai Kelimpahan Relatif ( Kr) hasil tangkapan

\begin{tabular}{|c|c|c|}
\hline No & Jenis ikan & (Kr) \% \\
\hline \multicolumn{3}{|c|}{ Ikan Target } \\
\hline 1 & Bawal Putih (Rhinoprenes Pentanemus) & 54,47 \\
\hline 2 & Bawal Hitam (Parastromateus niger) & 0,38 \\
\hline 3 & Kakap Batu (Lantjanus griseus) & 11,67 \\
\hline 4 & Terubuk (Lebtobrama sp) & 20,23 \\
\hline 5 & Kuro (Polydactylus plebiu) & 2,33 \\
\hline 6 & Gulamah (Argyrosomus amoyensis) & 3,11 \\
\hline 7 & Kakap Putih (Lates Calcalifer) & 3,11 \\
\hline 8 & Kakap Cina (Nibea Sguamaosa) & 0,77 \\
\hline 9 & Tenggiri (comberomorus comeroso) & 0,38 \\
\hline 10 & Kurau (Eleutheronema tetradactylum) & 3,11 \\
\hline 11 & Tembang (hryssa scratchleyi) & 0,38 \\
\hline Jumlah & & 100 \\
\hline Jumlah & & 157 \\
\hline \multicolumn{3}{|c|}{ Ikan Non Target } \\
\hline 1 & Baung Putih Cinetodus crassilabris) & 82,75 \\
\hline 2 & Baung Merah (Cinetodus froggatti) & 3,44 \\
\hline 3 & Pari Burung (Rhinoptera javanica) & 3,44 \\
\hline 4 & Sembilan (Polototus canus) & 3,44 \\
\hline 5 & Lidah (Cynoglossus Lingua) & 3,44 \\
\hline 6 & Hiu (Carcharhinus amboinensis) & 3,44 \\
\hline \multicolumn{2}{|c|}{ Jumlah (\%) } & 100 \\
\hline \multicolumn{2}{|c|}{ Jumlah ekor } & 29 \\
\hline \multicolumn{2}{|c|}{$\begin{array}{l}\text { (Scomberomorus commerson), Tembang } \\
\text { (Thryssa scratchleyi) sebesar } 0,38 \% \text {. }\end{array}$} & $\begin{array}{l}\text { indeks keanekaragaman yaitu 1,6960 } \\
\text { menunjukkan bahwa keanekaragaman } \\
\text { sedang, penyebaran jumlah, individu tiap } \\
\text { spesies sedang. Melmambessy et al. (2018) } \\
\text { bahwa indeks keanekaragaman sedang }\end{array}$ \\
\hline \multicolumn{2}{|c|}{ Indeks keanekaragaman $\left(\mathrm{H}^{\prime}\right)$} & diduga karena ikan yang mendominasi \\
\hline \multirow{3}{*}{\multicolumn{2}{|c|}{$\begin{array}{l}\text { Nilai indeks keanekaragaman }\left(\mathrm{H}^{\prime}\right) \\
\text { berturut-turut ikan target adalah } 1,41 \\
\text { dengan kategori keanekaragaman sedang. } \\
\text { Hal ini searah dengan Lantang et al. (2019) } \\
\text { bahwa nilai indeks keanekaragaman jenis } \\
\text { ikan yang tertangkap selama tiga bulan di }\end{array}$}} & $\begin{array}{l}\text { setiap daerah penangkapan sedikit. Hal ini } \\
\text { menunjukan bahwa selama penelitian nilai } \\
\text { keanekaragam ikan target tergolong sedang }\end{array}$ \\
\hline & & penyebaran individu tiap spesies sedang \\
\hline & & $\begin{array}{l}\text { serta kestabilan setiap komunitas sedang. } \\
\text { Odum (1971) keanekaragaman jenis tinggi }\end{array}$ \\
\hline \multicolumn{2}{|c|}{ Sungai Kumbe Distrik Malind yaitu 2,17 yang } & bila banyak jenis yang mendominasi \\
\hline menun & keanekaragaman $\quad$ sedang. & ekosistem tersebut,dan \\
\hline $\begin{array}{l}\text { Ulukya } \\
\text { hasil } p\end{array}$ & $\begin{array}{l}\text { et al. (2019) menyatakan bahwa } \\
\text { tian di Sungai Kumbe dengan }\end{array}$ & $\begin{array}{l}\text { rendah apabila hanya satu beberapa jenis } \\
\text { saja yang mendominasi komunitas tersebut. }\end{array}$ \\
\hline
\end{tabular}


Sementara ikan non target untuk indeks keanekaragaman dengan 0,73, dengan kategori keanekaragaman rendah. Odum (1971) bahwa rendahnya nilai indeks keanekaragaman sangat dipengaruhi oleh faktor jumlah spesies, jumlah individu dan penyebaran individu pada masing-masing spesies. Selain faktor-faktor tersebut terdapat juga beberapa faktor antara lain faktor waktu penangkapan atau musim pemijahan.

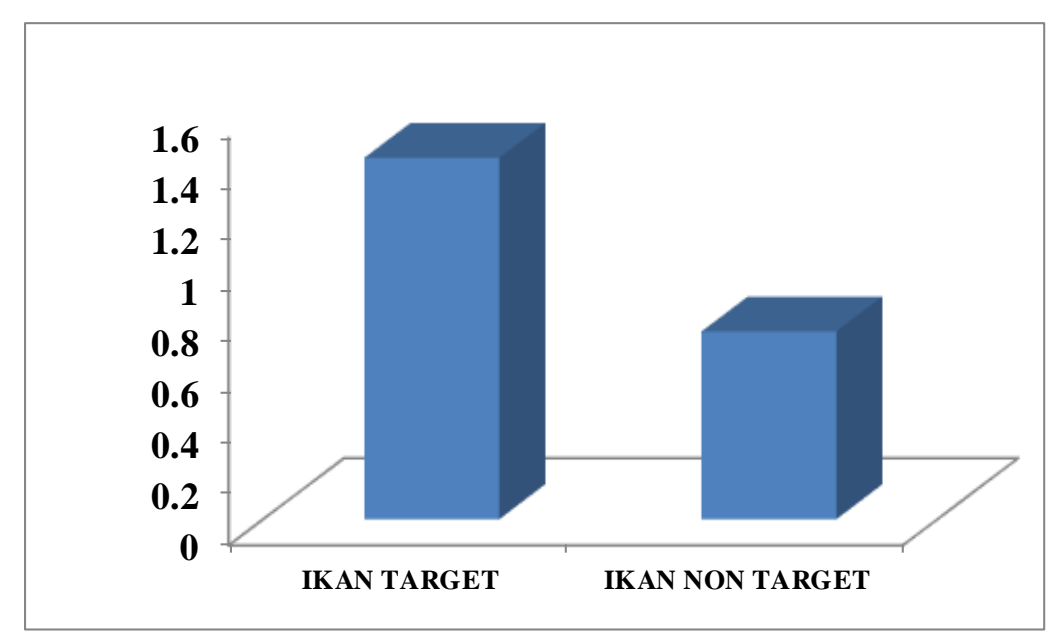

Gambar 2. Grafik Nilai Keanekaragaman

Sesuai dengan hasil penelitian, indeks keanekaragaman ikan target sebesar 1,41 dan digolongkan bahwa dalam perairan sungai tersebut keanekaragaman ikan yang tertangkan dalam kategori sedang. Pada ikan non target sebesar 0,73 dengan kategori keanekaragaman rendah.

\section{Indeks Dominansi}

Dari tabel 3 menunjukkan bahwa nilai indeks dominansi ikan target setiap spesies berbeda - beda. Indeks dominansi tertinggi diperoleh pada Ikan Bawal Putih (Rhinoprenes Pentanemus) dengan nilai 0,29 dan terendah pada ikan Ikan Kakap Batu (Latjanus griseus) dengan nilai 0,011. Untuk indeks dominansi keseluruhan dari semua spesies pada ikan target diperoleh nilai indeks dominansi sebesar 0,37 atau tidak ada jenis yang mendominansi. 
Tabel 3. Nilai dominansi jenis ikan target

\begin{tabular}{lc}
\hline \multicolumn{1}{c}{ Spesies } & Total \\
\hline Ikan Bawal Putih (Rhinoprenes Pentanemus) & 0,29 \\
\hline Ikan Bawal Hitam (Parastromateus niger) & 0,02 \\
\hline Ikan Kakap Batu (Latjanus griseus) & 0,011 \\
\hline Ikan Terubuk (Lebtobrama sp) & 0,03 \\
\hline Ikan Kuro (Polydactylus plebiu) & 0,02 \\
\hline Ikan Gulamah (Agryrosomus amoyenis) & 0,07 \\
\hline Ikan Kakap putih (Lates Calcalifer) & 0,07 \\
\hline Ikan Kakap Cina (Nibea squamaosa) & 0,06 \\
\hline Ikan Tenggiri (Scomberomorus commerson) & 0,02 \\
\hline Ikan Kurau (Eleutheronema tetradactylum) & 0,07 \\
\hline Ikan Tembang (Thryssa scratchleyi) & 0,02 \\
\hline \multicolumn{1}{c}{ Total Ikan Target } & 0,37 \\
\hline
\end{tabular}

Sesuai Tabel 3 diatas, diketahui bahwa pada ikan non target nilai indeks dominansi tertinggi diperoleh pada ikan Baung Putih (Cinetodus crassilabri) dengan nilai 0,6849 dan terendah pada Ikan Baung Merah
(Cinetodus froggatti), Ikan Pari (Mantabirosis), Ikan Sembilan (Clarias griepinus), Ikan Lidah (Cynoglossus lingua), Ikan Hiu (Carcharhinus amboinensi) dengan nilai indeks dominansi 0,0012 .

Tabel 4. Nilai indeks dominansi jenis ikan non target

\begin{tabular}{lcc}
\hline \multicolumn{1}{c}{ Spesies } & Jumlah & Total \\
\hline Ikan Baung Putih (Cinetodus crassilabri) & 24 & 0,6849 \\
\hline Ikan Baung Merah (Cinetodus froggatti) & 1 & 0,0012 \\
\hline Ikan Pari (Mantabirosis) & 1 & 0,0012 \\
\hline Ikan Sembilan (Clarias griepinus) & 1 & 0,0012 \\
\hline Ikan Lidah (Cynoglossus lingua) & 1 & 0,0012 \\
\hline Ikan Hiu (Carcharhinus amboinensi) & 1 & 0,0012 \\
\hline \multicolumn{1}{c}{ Total Ikan Non Target } & 29 & 0,6908 \\
\hline
\end{tabular}

Nilai indeks dominansi ikan target yang tertangkap pada lokasi penelitian selama tiga bulan yaitu 0,37 yang menunjukkan bahwa diantara jenis ikan yang ditemukan tidak ada yang mendominansi. Lantang et al. (2019) ${ }^{b}$ bahwa nilai indeks dominansi jenis ikan yang tertangkap selama tiga bulan di Sungai Kumbe Distrik Malind yaitu 0,20775. Indeks keragaman jenis menunjukan bahwa tidak ada ikan yang mendominansi. 
Selanjutnya

berdasarkan

keseluruhan spesies ikan target yang tertangkap nilai indeks dominansi terbesar yaitu spesies Ikan Bawal Putih (Rhinoprenes Pentanemus) yang diperoleh pada saat penangkapan dengan nilai dominansinya 0,29. Odum (1996) nilai indeks dominansi berkisar antara 0-1; indeks 1 menunjukkan dominansi oleh satu jenis spesies sangat tinggi (hanya terdapat satu jenis pada satu stasiun). Sedangkan indeks 0 menunjukkan bahwa diantara jenis-jenis yang ditemukan tidak ada yang dominansi. Meningkatnya nilai indeks domonansi pada ikan Bawal Putih (Rhinoprenes Pentanemus) diduga disebabkan karena ikan ini memliki kemampuan yang luas sehingga dapat hidup atau beradaptasi dengan lingkungan sekitarnya. Hal tersebut menjelaskan bahwa jenis ikan Bawal Putih mampu bertahan hidup pada daerah aliran sungai yang deras namun banyak juga ditemukan pada aliran sungai yang tenang seperti pada daerah sungai Maro .

Berdasarkan penelitian di Muara sampai Kawasan Gudang Arang Sungai Maro hasil yang berbeda pada jenis ikan non target yang memiliki nilai kelimpahan relatif tertinggi pada jenis ikan yang tertangkap selama penelitian yaitu 0,69 yang menunjukkan bahwa diantara jenis ikan yang ditemukan tidak ada yang mendominansi. Hal ini searah dengan Ulukyanan (2019) dengan nilai indeks dominansi 0,2938 yang menunjukkan bahwa diantara jenis - jenis ikan yang tertangkap di Sungai Kumbe tidak ada yang mendominansi. Legendre (1983) nilai 0 menunjukkan bahwa hampir tidak ada spesies yang mendominasi. Tetapi berdasarkan spesies ikan non target yang tertangkap nilai indeks dominansi terbesar secara umum yang mendekati angka 1 yaitu Ikan Baung Putih (Cinetodus crassilabri) memiliki nilai dominansi 0,68. Legendre (1983) menyatakan dominansi jenis sering terjadi karena beberapa hal antara lain kompetisi pakan alami oleh jenis tertentu yang disertai perubahan kualitas lingkungan, tidakseimbangnya antara predator dan mangsa sehingga terjad ikompetisi antar jenis.

\section{KESIMPULAN}

1. Komposisi hasil tangkapan ikan target dan non target di Muara sampai Kawasan Gudang Arang Sungai Maro sebanyak 17 spesies yang terdiri dari 11 jenis ikan target dan 6 jenis ikan non target.

2. Kelimpahan relatif hasil tangkapan pada ikan terget tertinggi diperoleh pada ikan Bawal putih (Rhinoprenes Pentanemus) dengan nilai $54,47 \%$ sedangkan pada ikan non terget tertinggi pada ikan 
Baung Putih (Cinetodus crassilabri) dengan nilai $82,75 \%$.

3. Indeks keanekaragaman $\left(\mathrm{H}^{\prime}\right)$ hasil tangkapan jenis ikan target sebesar 1,41 sehingga dikategorikan keanekaragamannya sedang, pada jenis ikan non target diperoleh 0,73 dan tergolong rendah.

4. Tidak terdapat jenis yang mendominansi dari hasil tangkapan, baik ikan target dan ikan non target.

\section{DAFTAR PUSTAKA}

Allen, G.R., 1989. Freshwater Fishes of Australia. T.F.H. Publications, Inc., Neptune City, New Jersey.

Allen, G.R., K.G. Hortle and S.J. Renyaan, 2000. Freshwater Fishes of the Timika Region New Guinea. PT Freepoert Indonesia. 1-175.

Astuti, L.P., A. Warsa. 2008. Inventarisasi Sumberdaya Ikan di Sungai Maro bagian Tengah Kabupatern Merauke. Prosiding Seminar Nasional Ikan V. Bogor.

Krebs. C. J. 1989. Ecology Methodology. Hal.293-368. Harper Collins Publishers New

Lagler, K. F. 1972. Freshwater Fishery Biology. 2nd Edition. Wm. C.Brown Company Publishers. Dubuque. Lowa. $421 \mathrm{~h}$.

Legendre, L dan P. Legendre, 1983. Numerical Ecology. Elsevier Scientific Publish Company. Amsterdam. Netherland. 419h.
Lantang, B. 2015. Komposisi Jenis Ikan dan Pengaruh Faktor Lingkungan pada Ikan yang Tertangkap Di Muara Sungai Maro Kabupaten Merauke. Laporan Penelitian Mandiri (tidak dipublikasikan). Jurusan Manajemen Sumberdaya Perairan FAPERTA UNMUS. Merauke.

Lantang, B., E.H.P. Melmambessy. (2019) ${ }^{a}$. The Effect of Physical-Chemical Faktors on the Existance of Kurau Fish in Maro Estuary of Merauke District. International Journal of Civil Engineering and Technology (IJCIET). Volume 10 No. 2, pp : 4047. IAEME Publication.

Lantang, B., E.H.P. Melmambessy. (2019) ${ }^{\text {b. }}$ Composition of Types of Fish that is Captured with the Gill Nets In Kumbe River, Malind District, Merauke Regency. International Journal of Civil Engineering and Technology (IJCIET). Volume 10 No. 3, pp : 400-410. IAEME Publication.

Melmambessy, E.H.P., M.A. Welliken, I. Latupeirissa and N. Monika. 2018. Assessment and Composition of Fish in the River District Maro Merauke. Publication Name: E3S Web of Conferences vol. 73, 21 December 2018

Merauke dalam Angka. 2011. Badan Pusat Statistik Kabupaten Merauke. Kabupaten Merauke.

Mote, N., S. Ayarau., S. Elviana. 2019. Kelimpahan Jenis Ikan Di Muara Sungai Maro Kelurahan Karang Indah Merauke, Papua. Jurnal Ilmu Perairan (Aquatic Science). Volume 1 Nomor 1 e-ISSN 2656-6389. 
Odum, E.P. 1971. Fundamental of Ecology. Third Edition. W. B. Saunders Company, Philadelphia. 546h.

Royce. W. F. 1972. Introduction to the fisheries sciences. Academic Press, inc. New York. 351 hal.

Ulukyanan K.V., E.H.P. Melmambessy., Lantang, B. 2019. Perbandingan Hasil Tangkapan Ikan dengan Jaring Insang (Set Gill Net) pada Siang dan Malam Hari di Sungai Kumbe Distrik Malind Kabupaten Merauke. Jurnal Musamus Fisheries and Marine Journal. Volume 1 No. 2 hal 34-45. Jurusan Manajemen Sumberdaya Perairan Fakultas Pertanian Universitas Musamus. Merauke.

Welliken, M.A.K 2013. Jenis dan Komposisi Ikan Yang Tertangkap Dengan Jaring Insang (Gill Net) Di Sungai Maro Kawasan Gudang Arang Kelurahan Maro Kabupaten Merauke. Skripsi Sarjana, Fakultas Pertanian, Universitas Musamus, Merauke.(Tidak Dipublikasikan). 